\title{
From pragmatic competence to intercultural competence: Pakistani ESL teachers perspectives of teaching interculturality in ESL classroom
}

\author{
De la competencia pragmática a la competencia intercultural: perspectivas de los \\ profesores de ESL de Pakistán sobre la enseñanza de la interculturalidad en el aula de \\ ESL
}

\section{Da competência pragmática à competência intercultural: Perspectivas dos professores de ESL do Paquistão de ensino da interculturalidade em sala de aula de ESL}

\begin{abstract}
In recent years, the areas of intercultural pragmatics and transcultural pragmatics under the phenomenon of "interculturality" have been investigated by linguists and language scholars because interculturality has a deep-rooted connection with the language and second language teaching and learning. This data-oriented study follows a quantitative research design. The data is collected through a survey questionnaire from 75 English teachers who are teaching at the university level in five different public and private sector universities in Pakistan. The overall results encourage embedding the knowledge of interculturality in ESL/EFL classes. There is a need to organize training sessions for teachers because many teachers reported that they do not utilize such skills in their ESL/EFL classrooms. In addition, the majority of teachers also believed in employing new approaches for teaching transcultural pragmatics to their students. This study further highlights that teacher/educators could also benefit from working together to develop the teaching of interculturality and transcultural competence, and to make this development happen in relation to teacher professional development.
\end{abstract}

\section{Resumen}

En los últimos años, las áreas de pragmática intercultural y pragmática transcultural bajo el fenómeno de la "interculturalidad" han sido investigadas por lingüistas y estudiosos de la lengua porque la interculturalidad tiene una conexión profunda con la enseñanza y el aprendizaje de lenguas y segundas lenguas. Este estudio orientado a datos sigue un diseño de investigación cuantitativo. Los datos se recopilan a través de un cuestionario de encuesta de 75 profesores de inglés que enseñan a nivel universitario en cinco universidades diferentes del sector público y privado en Pakistán. Los resultados generales fomentan la incorporación del conocimiento de la interculturalidad en las clases de ESL / EFL. Existe la necesidad de organizar sesiones de capacitación para maestros porque muchos maestros informaron que no utilizan tales habilidades en sus aulas de ESL / EFL. Además, la mayoría de los profesores también creían en el empleo de nuevos enfoques para enseñar pragmática transcultural a sus alumnos. Este estudio destaca además que los docentes / educadores también podrían beneficiarse de trabajar juntos para desarrollar la enseñanza de la interculturalidad y la competencia transcultural, y hacer que este desarrollo ocurra en relación con el desarrollo profesional docente.

\footnotetext{
${ }^{12}$ M. Phil Scholar, Department of English, University of Central Punjab Lahore Pakistan.

${ }^{13}$ Assistant Professor, Department of English, University of Central Punjab Lahore Pakistan.

${ }^{14}$ Lecturer, English Language Centre, University of Central Punjab Lahore Pakistan.

${ }^{15}$ Lecturer, English Language Centre, University of Central Punjab Lahore Pakistan.
} 
Keywords: Interculturality; intercultural pragmatics; transcultural pragmatics; language scholars; teacher education.
Palabras llave: interculturalidad; pragmática intercultural; pragmática transcultural; eruditos del lenguaje; formación del profesorado.

\section{Resumo}

Nos últimos anos, as áreas da pragmática intercultural e da pragmática intercultural sob o fenômeno da "interculturalidade" foram investigadas por lingüistas e estudiosos da língua porque a interculturalidade tem uma conexão profunda com o ensino e a aprendizagem de línguas e segundas línguas. Este estudo orientado a dados segue um desenho de pesquisa quantitativa. Os dados são coletados por meio de um questionário de pesquisa com 75 professores de inglês que ensinam em nível universitário em cinco diferentes universidades dos setores público e privado no Paquistão. Os resultados gerais promovem a incorporação do conhecimento da interculturalidade nas aulas de ESL / EFL. Há uma necessidade de organizar sessões de treinamento de professores porque muitos professores relataram que não usam essas habilidades em suas salas de aula de ESL / EFL. Além disso, a maioria dos professores também acreditava no emprego de novas abordagens para ensinar pragmática intercultural a seus alunos. Este estudo destaca ainda que os professores / educadores também podem se beneficiar do trabalho conjunto para desenvolver o ensino da interculturalidade e da competência intercultural, e que esse desenvolvimento ocorra em relação ao desenvolvimento profissional do professor.

Palavras-chave: interculturalidade; pragmática intercultural; pragmática transcultural; estudiosos de línguas; treinamento de professor.

\section{Introduction}

English, as a lingua franca in today's globalizing world, is becoming the language of transcultural mobility, the language of the third space, and a language of hybridity (see Baker, 2017). Yang (2018) argues that the challenge for English learners in today's intercultural contexts is that "social rules are in constant flux; what is appropriate depends on the unique linguistic and cultural backgrounds of the interlocutors, and the specific context in which they are communicating" (p.361). Misunderstandings and misconceptions are regularly brought about by discourse differences as shaped by culture (Zhu et al., 2020). Researchers (Chau \& Truong, 2019; Corder et al., 2018; Prapinwong, 2018; Ramirez, 2018) believe teachers as well as learners must recognize the importance of the relationship between language and culture. Hence, communicative competence, as suggested by Vaganova (2019), has yielded place for intercultural communicative competence which Syzenko and Diachkova (2020) describe as the ability of second-language speakers to mediate/interpret the values, beliefs and behaviors (the 'cultures') of themselves and of others and to 'stand on the bridge' or indeed 'be the bridge' between people of different languages and cultures (p.12). Yates (2015) integrated interlanguage pragmatics, sociocultural pragmatics, intercultural pragmatics, intercultural communication, and cross-cultural communication into transcultural pragmatics. Transcultural pragmatics awareness is "the ability to decipher how cultures, cultural mixing, and contextual factors shape language use and communication in intercultural contexts" (Oranje \& Smith, 2018). Transcultural pragmatics entails interculturality. Yang (2018) argues that interculturality is "a situationally emergent and co-constructed phenomenon that relies both on relatively definable cultural norms and models as well as continually evolving features" (p. 67). In order to develop the transcultural pragmatics competence, teachers and learners need not to concentrate on teaching pragmatics models in a second language and the foreign culture. Instead, He (2019) suggests that teachers can "explicitly invite learners to compare and contrast the target culture with their own culture(s)" (p. 43) and discuss how the differences and similarities shape each interlocutor's unique language use in specific intercultural communicative situations (Zaferanieh et al., 2020).

Interculturality links language and culture in such a way that complexities of contextual factors become visible to allow us to communicate with various people. Teachers and learners can develop awareness about intercultural communicative competence through transcultural communicative competence. One of the challenges for Pakistani ESL teachers is how to develop transcultural as well as intercultural communicative competence of their ESL learners in Pakistani settings, and 


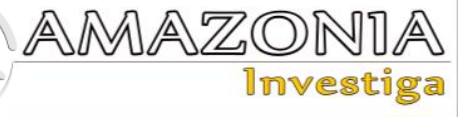

how can they inculcate these skills in their students in a transnational context.

This inspiring new focus on interculturality prompts us to link not only language and culture, but also language use and the intricacies involved in the process of interacting with different people whose communication styles are shaped by a variety of contextual factors. To understand what status these skills enjoy in the instructions of Pakistani ESL teachers, we sought the belief and perception of 75 ESL teachers towards teaching and developing interculturality and transcultural pragmatics.

\section{Method and Material}

This data-oriented study follows a quantitative research design. The major focus of the study remains in examining the Pakistani EFL teachers' perception regarding "Interculturality" as a pedagogical approach in teaching English as a foreign language. The descriptive inferential analysis is presented to highlight the significance of Interculturality in the Pakistani context.

\section{Participants}

The sample consisted of 75 teachers, who were, at the time of conducting this research, teaching at the Punjab University Lahore, Government College University Lahore, University of Central Punjab, University of Lahore, and Kinnaird College Lahore. Like other universities of Pakistan, the medium of instruction is English in these universities as well. All the EFL teachers from the universities were provided questionnaires (see Appendix A). Selected teachers were teaching English in each university but had a different academic background with respect to the subfields (literature, linguistics, applied linguistics (AL), and ELT/TESL/TEFL) they had studied through and completed their degrees. Moreover, their teaching experiences were also different in terms of duration of teaching at the university. Among 75, 24 were PhD's and remaining were MPhil. There were only 25 respondents that belonged to other disciplines of English (literature, 25), in contrast with those (50) who belonged to linguistics and Ling/AL/TESL/TOEFL/ELT. This variation proved to be helpful in the way that the respondents had different opinions towards the items of the questionnaire. However, there was unanimity among all the respondents with respect to the point that cultural variations hinder the EFL learners understanding the skills of communication with certain expertise and that there should be full-fledged training schemes not only for EFL teacher but also for EFL learners for achieving the said skills in communication.

\section{Instrumentation}

Data for this study were collected through a questionnaire that has 15 items in Likert-scale form containing responses from strongly agree to strongly disagree (5-1, see Appendix A). As mentioned earlier, the research design is quantitative because of using close-ended questions in this research. The questionnaire used in the current study was adopted from Suwanarak (2017) study, and a few items were adapted after the pilot study. The questionnaire includes components related to eliciting Pakistani teacher's beliefs about developing ESL/EFL transcultural pragmatics. Keeping in view the idea of interculturality, in the current instrument, 8 items focused on eliciting data related to intercultural competence, and 7 items were designed to cover the culture-specific pragmatics features namely "mental sets" (Yates, 2015), "schemata" (Yates, 2015), "scripts" (Yates, 2015), "speech events" (Yates, 2015), "sociocultural norms" (Barraja-Rohan, 2000), "linguistic etiquette" (Kasper, 1997), and "pragmatics accent" (Yates, 2015). The instrument used in the current study is based on two dimensions that provide us the perceptions of Pakistani ESL/EFL teachers regarding the importance of teaching target culture and culturebased ethics.

\section{Validity and Reliability}

The questionnaire was pilot tested with 25 teachers from Pakistani universities, with positive score of coefficient reliability $(\alpha=.86)$. Further, the questionnaire was checked by to inter-raters. The raters' judgments were recognized through Cohen's kappa $(\kappa=.89)$. In addition, the questionnaire was proofread, checked and rechecked many times by statisticians, researchers, teachers of English to avoid ambiguity and multiple meanings.

\section{Data Collection and Data Analysis}

We personally visited the selected universities and got permission from the HoD's of the departments. After having sought permission, we formally invited the participants to take part in the research. All the participants showed their consent to take part in the study, then they were given the questionnaires with the request to take 20-25 minutes to fill the survey. All the questionnaire items were clearly explained to the participants. Eventually, the data were analyzed 
by using SPSS (21-local version) software. All the scores of the questionnaire responses were then analyzed. As the questionnaire was designed with close-ended questions, it was easy to numerically analyze the data. Responses from the teachers were, then, put in the tables to describe statistically. The mean values and standard deviations helped to understand the scope of each statement with respect to the teachers.

\section{Findings and Discussion}

As mentioned earlier, the data of the current research were analyzed through SPSS (21-local version) in order to answer the research questions. It can be seen in table 1 that the mean score of the first statement, it is important to have the knowledge of a foreign culture in order to know a foreign language remained $(\mathrm{M}=3.68$, $\mathrm{SD}=1.21)$. As the question of knowing the target language culture is quite significant. Results indicate that participants agreed to be familiar with the target culture is important in order to impart quality language teaching. The traditional practice of the majority of Pakistani institutions is to teach grammar with parallel corpus in Urdu to get it translated. Most of the students, who know the grammar and structural regulations of a language are unable to interact in that language appropriately. This is because they have not acquired enough knowledge about that culture (Haggerty, 2020; Hoa, 2018). Solhaug and Kristensen (2020) state that teachers feel reluctant to teach culture with the language, as mostly they tend to teach the four skills of listening, speaking, reading and writing (Vaganova, 2019). It can be suggested that there should be training for teachers to get them aware of these aspects (Baker, 2017).

Table 1.

Teacher perceptions regarding teaching interculturality in their ESL classrooms.

\begin{tabular}{|c|c|c|c|}
\hline Sr. No & Statements & Mean & $\begin{array}{l}\text { Standard } \\
\text { Deviation }\end{array}$ \\
\hline 1 & $\begin{array}{l}\text { Importance of target culture for teaching the target } \\
\text { language }\end{array}$ & 3.68 & 1.21 \\
\hline 2 & Importance of source culture for the target language & 3.52 & 1.12 \\
\hline 3 & Comparing cultures make language learning easy & 4.08 & 0.70 \\
\hline 4 & Curiosity to learn culture reduces pragmatics failure & 4.16 & 0.55 \\
\hline 5 & Respecting target culture is important for ESL learners & 3.56 & 1.22 \\
\hline 6 & Teachers can teach contextual effects on meaning & 4.12 & 0.72 \\
\hline 7 & Copying natives helps ESL to improve communication & 3.56 & 0.91 \\
\hline 8 & $\begin{array}{l}\text { Mental sets are important to know the contextual } \\
\text { meaning }\end{array}$ & 3.92 & 0.95 \\
\hline 9 & Schema is important to know the contextual meaning & 3.96 & 0.78 \\
\hline 10 & Scripts are important to know the contextual meaning & 3.76 & 0.59 \\
\hline 11 & Speech acts are important for purposeful interaction & 4.08 & 0.70 \\
\hline 12 & Sociocultural norms help to know the contextual meaning & 4.00 & 0.40 \\
\hline 13 & Linguistic etiquettes help to know the contextual meaning & 3.92 & 0.90 \\
\hline 14 & Pragmatics accent helps to know the contextual meaning & 3.52 & 1.12 \\
\hline 15 & Explicit use of language is helpful for desired results & 3.80 & 1.00 \\
\hline
\end{tabular}

The second statement importance of source culture for the target language showed moderate mean score $(\mathrm{M}=3.52, \mathrm{SD}=1.12)$. This question showed moderate mean value, which means, teacher to great extent believe that for target language, leaners need to evaluate not only the 


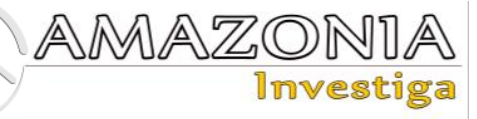

target language culture but also to scrutinize their own cultural traits, norms and values as well (Ho et al., 2020). This shows that a few teachers kept the view of Oranje and Smith (2020) in mind that one's own culture helps learning the other cultures by unveiling the differences in behaviors towards their languages and use of language that can be helpful to avoid pragmatic failure. There should be a flexible environment for learning another language without any strict rules rather there should be an encouragement for students to present themselves according to their own choice (Wang et al., 2020).

The third statement comparing cultures makes language learning easy the mean score remained $(\mathrm{M}=4.08, \mathrm{SD}=0.70)$. Fioramonte and Vasquez (2019) argue that leaners who critically examine the culture-specific language behaviour of themselves and target culture interlocutor perform better during intercultural interactions. Ho et al. (2020) opine that comparing cultures makes target language learning process relaxed because learners can understand the nuances of high-context and low-context, individualist and collectivist, and status conscious and status neutral factors.

The fourth statement curiosity to learn culture reduces pragmatic failure the score was higher than that of the previous statements showing the mean score $(\mathrm{M}=4.16, \quad \mathrm{SD}=0.55)$. This is something interesting to note that the teachers, with no exception to their subjects of degrees, did not negate the need to arouse interest in students to make them learn the culture of a particular language. Researchers (Ho, 2020; Baker, 2017; Kramsch, 2020) suggest that curiosity to learn culture leads to an awareness of how the target language is used in actual communication shaped by the socio-cultural contexts. Further, Ellis (2017) recommends learning target culture often includes development of abilities for dealing with speech acts, language functions, and linguistics politeness with an emphasis of realworld relevance.

The fifth statement, "respecting target culture is important for EFL learners" secures mean score $(\mathrm{M}=3.56, \mathrm{SD}=1.22)$. As mentioned earlier, when learners compare and contrast their own culture with respect to target language culture, they become quite familiar with the do's and don'ts of target language culture. In this way, they start taking care of the target language culture in order to reduce the occurrence of pragmatic failure (Yang, 2018). Kramsch (2020) argues that students who do not know about others' cultures perceive certain misconceptions which may lead to miscommunication and break-down of communication. Such an attitude proves a hindrance in their way to learning target culture language appropriately (Solhaug \& Kristensen, 2020). Moreover, Ho and Ton (2020) argue "successful communication involves, besides linguistic forms, respect for and understanding of each other's culture, mutual negotiations in the interaction, and the ability to interpret the intentions of the interlocutor". We believe that these latter abilities must be incorporated in a curriculum/program where English is expected to be taught in a globalization environment. Thus creating a bridge of respect is necessary for nurturing culture-based learning of second or foreign language. Pakistani culture has certain things (high-context, collectivist, status conscious, gender conscious, non-verbally oriented, linear and deductive culture) which are different from those found in countries where English enjoys the status of mother language or first language (Saleem \& Anjum, 2018). Current result indicates that Pakistani teachers may need to develop interculturality among their learners to better understand commonalities and differences of target language culture.

The sixth statement, teachers can clarify their students regarding the effects of context on meaning in communication, the mean score of this statement $(\mathrm{M}=4.12, \mathrm{SD}=0.72)$ shows that Pakistani teachers believe in teaching contextual effects on meaning. Saleem and Anjum (2018) argue that in Pakistan context, Pakistani teachers hardly provide any opportunity to EFL learners to understand and inculcate the nuances of context and its effects on meaning which may be imparted through explicit teaching techniques (Khukhlaev et al., 2020). Toyoda (2018) considers the context of second/foreign language imperative and can be inculcated among learners if they are trained by implementing contentbased instruction (CBI) and task-based instruction (TBI).

The seventh statement, copying natives helps EFL to improve communication showed a mean score $(\mathrm{M}=3.56, \mathrm{SD}=0.91)$. The mean score indicates that a few Pakistan teachers are of the opinion that Lingua Franca Core features need to be sustained. Wang and Zee (2013) suggest though the emphasis of English teaching has shifted from linguistic forms to meaning negotiation and accommodation, and (Kramsch, 2014; Jenkins, 2007) "the norms that are followed in current curriculum, e.g. British or American 'Standard English', need not be modified, and no Lingua Franca Core needs to be established for teaching purposes". Jenkins 
(2007) proposes that there is no need to tell the students not to worry about the pronunciation of th because it is a non-core feature. The students still need to be instructed on the pronunciation of the sound, whether they can master it or not.

The eighth statement, mental sets are important to know the contextual meaning carries a mean score of $(\mathrm{M}=3.92, \mathrm{SD}=0.95)$. The findings show that English teachers in this study would prefer to utilize the technique mental sets for the development of interculturality among their students. It is significant to elucidate that mental sets are "a frame of mind involving an existing disposition to think of a problem or a situation in a particular way (Pergert et al., 2020); e.g. what is the meaning of an offer of coffee after a meal; is it an invitation by the host to stay a little longer or a polite hint to guests that it is time to leave"? The importance of mental sets cannot be underestimated. Saadatnejad (2020), while discussing the significance of improving intercultural competence argues the effects of mental sets. If correspondents do not know about each other's mental sets, based on cultural background, they may not understand the meanings of the utterances (Wang et al., 2020). EFL/ESL learners may be traninned to comprehend aspects of linguistic behavior in addition to learning speech acts that are suitable to the context (Kennedy, 2020).

The ninth statement schemata helps learners to better understand the context where they have to interact with people of another culture bears a mean score of $(M=3.96, \quad S D=0.78)$. It is heartening to notice that English teachers in the current study valued significantly the contribution of schemata in learning English as a foreign language. It is pertinent to mention that "a schema (plural: schemata) is an abstract structure of knowledge, a mental representation stored in memory upon which all information processing depends. It may represent knowledge at different levels, e.g. cultural truths, linguistic knowledge or ideologies" (Fioramonte \& Vasquez, 2019). Liu (2013) states that schemata provide missing information with the help of context, providing an example of a dialogue between a bank client and teller where teller and client successfully understand and respond each other's utterances with the help of existing knowledge of schema. According to Bradfield (2008), scientists dealing with cognitive sciences believe that knowledge becomes part of the mind in the structure of schemata that helps understand actions in a particular situation (Weinstock, 2013; Maxwell et al., 2013).
The tenth statement scripts help learners to better understand the context where they have to interact with people of another culture received a mean score of $(\mathrm{M}=3.76, \mathrm{SD}=0.97)$. The mean score indicates that English teachers in the current study like to favoure the provision of training regarding "script" in their classrooms. Script is based on a pre-existing knowledge structure for interpreting event sequences (Hoa, 2018); e.g. a visit to the doctor, shopping at a supermarket, phoning to make an appointment at a hairdressing salon, etc. Emmott et al. (2014) states that students using the script of their own culture face pragmatic failure while they perform any speech act. In this respect, Baker (2015) further argues that teachers must be sufficiently socialized to interculturality practices, so that they can comfortably draw on those practices as part of their communicative and cultural repertoire, and so that their metapragmatic awareness enables them to support students' developing interculturality effectively.

The eleventh statement, speech acts are important for purposeful interaction got $(\mathrm{M}=4.08, \mathrm{SD}=0.70)$ mean score. The results are very close to the fourth statement, which covers the aspect of understanding others' culture through curiosity. Researchers agree that knowledge of politeness behavior and speech act patterns help EFL/ESL learners better interact in the foreign language (Aziz et al., 2018; Kennedy, 2020). Thus, it may be included in the teaching curriculum and material of EFL classes in Pakistani institutions.

The twelfth statement, sociocultural norms help to know the contextual meaning achieved a score of $(\mathrm{M}=4.00, \mathrm{SD}=0.40)$. The methodology of teaching EFL should be based on teaching these values of that particular culture. Toyoda (2018) suggests that the information regarding sociocultural should be taught to the students. Rakhimova (2017) argues that knowledge of sociocultural norms helps in achieving competence in a foreign culture and at the same time the formation of this competence. Pergert and Tiselius (2020) state that sociocultural competence enables EFL/EFL learners to enhance their understanding regarding reflections of own culture and the ability to talk about it in a foreign language including achieving intercultural understanding, which leads to respect for others and tolerance. Moreover, sociocultural learning is not only the knowledge own and other cultures but also an ability to estimate own culture critically (Vaganova, 2019). Vaganova (2019) opines teaching foreign 


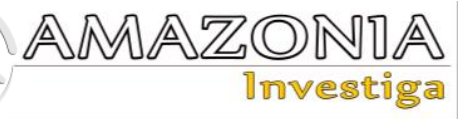

language in class is not just about language knowledge. Knowledge and skills in sociocultural sphere are essential in communicative competence. Many Western curricula for foreign language contain requirement that students should acquire sociocultural competence.

The thirteenth statement, linguistic etiquette of the target culture helps students understand how to communicate with respect to sociocultural factors (social distance, social power, and gender of interlocutors) of that culture secured a score of $(\mathrm{M}=3.92, \mathrm{SD}=0.90)$. The etiquettes related to use of language are worth teaching because students have to interact with people of other culture avoiding any misinterpretation. Baraja-Rohan (2020) states that the etiquette of communication represents the underlying behavior of a community. states that these behaviors are necessary to avoid blunders in communication. Language etiquette is a part of linguistic routines which Agyekum (Haggerty, 2020) defined as the sequential organizations beyond a sentence either as activities of one person or as the interaction of two or more people. Many of these routines are used in our everyday life during interactions. Kennedy (2020) argues the relationship between culture, etiquette, language etiquette and politeness can be described as: politeness is a subset of language etiquette, language etiquette is a subset of etiquette and etiquette is a subset of cultures. Therefore teachers need to know and understand what the reactions of their students from various cultural groups are likely to be, or they will not be effective teachers (Henrichsen, 1997).

The fourteenth statement, pragmatic accent of target culture helps learners understand the actual meaning of a conversation with a native of that culture got a score of $(\mathrm{M}=3.52, \mathrm{SD}=1.12)$. It is the pragmatic accent that people use to understand what is delivered unsaid while communicating with each other. Kramsch (2020) clarifies that what a speaker assumes can be grasped with the pragmatic accent with no direct words. Thus, the pragmatic accent is important to teach students how to understand an utterance with message unsaid. Baker $(2016,2017)$ states teachers must be sufficiently socialized to L2 pragmatic practices, so that they can comfortably draw on those practices as part of their communicative and cultural repertoire, and so that their metapragmatic awareness enables them to support students' learning of L2 pragmatics effectively (p.23). This is a challenging requirement to fulfill, given that much of our pragmatics knowledge is implicit and only becomes available to us through careful observation and conscious practice at distinguishing between expressed and implied meanings (Kramsch, 2020).

The fifteenth statement, explicit use of language is helpful for desired results achieved a score of $(\mathrm{M}=3.80, \mathrm{SD}=1.00)$. There are many instances where implicit and explicit expressions are employed in a conversation that the listener has to understand to continue the communication smoothly. Syzenko and Diachkova (2020) attempt to clarify the distinction between implicit and explicit use of language from some instances of everyday life where implicature and propositions conclude the meaning of the utterance. Many extensions of a word and many characteristics are available to choose. In such expressions, we learn, listener and speaker, have to make a common ground of context that helps them make all the meanings clear (Zhu et al., 2020). Teachers should teach the skills that are crucial for EFL learners in order to interact with the people of another community to have a productive conversation.

\section{Conclusion}

To gain an understanding of Pakistani EFL teachers' conception of teaching interculturality skills in their classrooms is pretty significant owing to recent developments in the field of transcultural pragmatics. This study investigates Pakistani EFL teachers' perception regarding focusing on interculturality to fill the gap. University level teachers from Pakistan were requested to respond to the questionnaire based on pragmatics knowledge. Participants of the current study agreed to be familiar with the target culture is important in order to impart quality language teaching. The traditional practice of the majority of Pakistani institutions is to teach grammar with parallel corpus in Urdu to get it translated. Most of the students, who know the grammar and structural regulations of a language are unable to interact in that language appropriately. This is because they have not acquired enough knowledge about that culture (Baraja-Rohan, 2020; Haggerty, 2020). Kennedy (2020) states that teachers feel reluctant to teach culture with the language, as mostly they tend to teach the four skills of listening, speaking, reading and writing. It can be suggested that there should be training for teachers to get them aware of these aspects (Kramsch, 2020). Teachers in the current study to great extent believe that for target language, leaners need to evaluate not only the target language culture but also to scrutinize their own cultural traits, norms and values as well 
(Syzenko \& Diachkova, 2020; Vaganova, 2019). In addition, participants believe that comparing cultures makes language learning easy (Kennedy, 2020) argues that leaners who critically examine the culture-specific language behaviour of themselves and target culture interlocutor perform better during intercultural interactions. Respondents of the current study endorsed the need to arouse interest in students to make them learn the culture of a particular language (Baker, 2016) suggests that curiosity to learn culture leads to an awareness of how the target language is used in actual communication shaped by the socio-cultural contexts. Teachers further reported that when learners compare and contrast their own culture with respect to target language culture, they become quite familiar with the do's and don'ts of target language culture. In this way, they start taking care of the target language culture in order to reduce the occurrence of pragmatic failure (Wag et al., 2020; Baker \& Sangiamchit, 2019). Kennedy (2020) argue that students who do not know about others' cultures perceive certain misconceptions which may lead to miscommunication and break-down of communication. It may be concluded that "English as a lingua franca was not addressed in textbook material, which revolved around British and American themes or factual knowledge about former colonies such as Australia and Canada" (Saleem \& Anjum, 2018). The results of current study can be interpreted as a step forward towards a re-interpretation of the knowledge- and skills dimension based on cultural studies and critical intercultural communication (Pergert \& Tiselius, 2020). This inspires a development of pluralistic discourses and engagement in interculturality, a process that supports education for democracy and empowerment of all students (Kramsch, 2015, 2017). Baker (2017) argues that teacher educators could also benefit from working together to develop the teaching of interculturality and intercultural competence, and to make this development happen in relation to teacher professional development.

\section{References}

Baker, W. (2015). Culture and complexity through English as a lingua franca: Rethinking competences and pedagogy in ELT. Journal of English as a Lingua Franca, 4(1), 9-30.

Baker, W. (2016). Culture and language in intercultural communication, English as a lingua franca and English language teaching: Points of convergence and conflict. In P. Holmes \& F. Dervin (Eds.), The cultural dimensions of
English as a lingua franca (pp. 70 - 89). Bristol, UK: Multilingual Matters.

Baker, W. (2017). English as a lingua franca and intercultural communication. In The Routledge handbook of English as a lingua franca. Londres: Routledge. (pp. 25-36).

Baker, W., \& Sangiamchit, C. (2019). Transcultural communication: language, communication and culture through English as a lingua franca in a social network community. Language and Intercultural Communication, 19(6), 471-487.

Barraja-Rohan, A.M. (2000). Teaching conversation and sociocultural norms with conversation analysis. In A.J. Liddicoat \& C. Crozet (Eds.), Teaching languages, teaching cultures. Melbourne: Applied Linguistics Association of Australia. (pp. 65-77)

Bradfield, R. M. (2008). Cognitive barriers in the scenario development process. Advances in Developing Human Resources, 10(2), 198-215. Chau, T. H. H., \& Truong, V. (2019). The Integration of Intercultural Education into Teaching English: What Vietnamese Teachers Do and Say. International Journal of Instruction, 12(1), 441-456.

Corder, D., Roskvist, A., Harvey, S., \& Stacey, K. (2018). Language teachers on study abroad programmes: The characteristics and strategies of those most likely to increase their intercultural communicative competence. In Second Language Study Abroad. Cham: Palgrave Macmillan, (pp. 257-297).

Ellis, N. C. (2017). Implicit and explicit knowledge about language. Language awareness and multilingualism, Berlín, Alemania: Springer. 1-12.

Emmott, C., Alexander, M., \& Marszalek, A. (2014). Schema theory in stylistics. The Routledge handbook of stylistics, 268-283.

Fioramonte, A., \& Vásquez, C. (2019). Multiparty talk in the medical encounter: Sociopragmatics functions of family members' contributions in the treatment advice phase. Journal of Pragmatics, 139, 132-145.

Haggerty, H. (2020). Integration of Culture in the Teaching of French as a Foreign Language at the University Level in Uganda. Emerging Perspectives: Interdisciplinary Graduate Research in Education and Psychology, 4(1), 19-24.

Ho, D. T. P., \& Ton, H. N. N. (2020). Factors influencing teachers' integrating intercultural communicative competence (icc) into business English teaching. Hue University Journal of Science: Social Sciences and Humanities, 129(6B), 5-14

Hoa, C. T. (2018). Integrating Cultures into Teaching EFL in Vietnam: Teachers' 


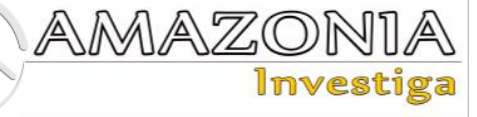

Perceptions. LEARN Journal: Language Education and Acquisition Research Network, 11(2), 103-115.

https://doi.org/10.34069/AI/2020.27.03.45

Jenkins, J. (2007). English as a lingua franca: Attitude and identity. Oxford: University Press. Kasper, G. (1997). Linguistic etiquette. In F. Coulmas (Ed.), The handbook of sociolinguistics. United Kingdom: Blackwell Publishers. (pp. 374-385).

Kennedy, J. (2020). Intercultural pedagogies in Chinese as a foreign language (CFL). Intercultural Education, 31 (4), 427-446. DOI:10.1080/14675986.2019.1702290

Khukhlaev, O. E., Gritsenko, V. V., Pavlova, O. S., Tkachenko, N. V., Usubian, S. A., \& Shorokhova, V. A. (2020). Comprehensive Model of Intercultural Competence: Theoretical Substantiation. RUDN Journal of Psychology and Pedagogics, 17(1), 13-28.

Kramsch, C. (2014). Teaching foreign languages in an era of globalization: Introduction. The modern language journal, 98(1), 296-311.

Kramsch, C. (2020). "I hope you can let this go"/“Ich hoffe, Sie können das fallen lassen"Focus on the Perlocutionary in Contrastive Pragmatics. Contrastive Pragmatics, 1(1), 58-81.

Liu, S. (2013). Introduction: Modernity, Interculturalism, and Hybridity. In Performing Hybridity in Colonial-Modern China (pp. 1-12). New York: Palgrave Macmillan.

Maxwell, B., Waddington, D. I., McDonough, K., Cormier, A. A., \& Schwimmer, M. (2013). Interculturalism, multiculturalism, and the state funding and regulation of conservative religious schools. Educational theory, 62(4), 427-447.

Oranje, J., \& Smith, L. F. (2018). Language teacher cognitions and intercultural language teaching: The New Zealand perspective. Language Teaching Research, 22(3), 310-329.

Pergert, P., \& Tiselius, E. (2020). Intercultural Competence and Communication over Language Barriers. In Ethical Issues in Pediatric Hematology/Oncology. Cham: Springer. (pp. 203-222).

Prapinwong, M. (2018). Developing Intercultural Awareness for Pre-Service Teachers In Thailand. ABAC Journal,38(2), 21-35.

Rakhimova, A. E. (2017). Sociocultural competence as one of the core competencies of the individual. Espacios, 38(45), 34.

Ramirez, E. (2018). Intercultural communicative language teaching (iCLT): a selection of practical points of departure. New Zealand Language Teacher, The, Vol 44, 18.
Saadatnejad, Z. (2020). Improving Intercultural Competence through Literary Texts and the Strategies of Teaching it in French Language. Language Related Research, 10(6), 345-372.

Saleem, T., \& Anjum, U. (2018). Positive and Negative Politeness: A Cross-Cultural Study of Responding to Apologies by British and Pakistani Speakers. International Journal of English Linguistics, 8(5), 71-86.

Solhaug, T., \& Kristensen, N. N. (2020). Gender and intercultural competence: analysis of intercultural competence among upper secondary school students in Denmark and Norway. Educational Psychology, 40(1), 120-140.

Syzenko, A., \& Diachkova, Y. (2020). Building Cross-Cultural Competence in a Foreign Language through Technology-Enhanced Project-Based Learning. Amazonia Investiga, 9(27), 411-418. Recovered from https://www.amazoniainvestiga.info/index.php/a mazonia/article/view/1257/1128

Toyoda, J. (2018). Review of The Impact of Learning Contexts on Proficiency, Attitudes, and L2 Communication: Creating an Imagined International Community (Tomoko Yashima and Lori Zenuk-Nishide, System, 36, 566-585.). Journal of Inquiry and Research, 108, 303-307.

Vaganova, O. I. (2019). Organization of practical classes in a higher educational institution using modern educational technologies. Amazonia Investiga, 8(23), 81-86. Recovered from: https://www.amazoniainvestiga.info/index.php/a mazonia/article/view/850/791

Wang, J., Chen, C., Liu, Y., Barkley, D., \& Wu, C. C. (2020). Intercultural competences and job satisfaction of expatriates: the mediating effect of positive psychological wellbeing. International Journal of Organizational Innovation, 12(3). 140-155

Weinstock, D. (2013). Interculturalism and multiculturalism in Canada and Quebec: Situating the debate. In Liberal multiculturalism and the fair terms of integration. London: Palgrave Macmillan (pp. 91-108)

Yang, P. (2018). Developing TESOL teacher intercultural identity: An intercultural communication competence approach. TESOL Journal, 9(3), 525-541.

Yates, L. (2015). Intercultural communication and the transnational: Managing impressions at work. Multilingua, 34(6), 773-795.

Zhu, H., Kramsch, C., Gramling, W. D., House, J., Johnson, J., Li, W., \& Park, J. (2020). Translating culture in global times: dialogues. Applied Linguistics, 41(1), 148-160. 